\title{
Quantification of the relationship between root parameters and soil macropore parameters under different land use systems in Retisol
}

\author{
Mykola Kochiieru ${ }^{1}{ }^{*}$, Krzysztof Lamorski ${ }^{2}$, Virginijus Feiza ${ }^{1}$, Dalia Feiziene $\dot{1}^{1}$, \\ and Jonas Volungevičius ${ }^{1}$ (D) \\ ${ }^{1}$ Institute of Agriculture, Lithuanian Research Centre for Agriculture and Forestry, \\ Instituto ave. 1, Akademija, Kedainiai district, Lithuania \\ ${ }^{2}$ Institute of Agrophysics, Polish Academy of Sciences, Doświadczalna 4, 20-290 Lublin, Poland
}

Received March 10, 2020; accepted June 2, 2020

\begin{abstract}
The study aimed to quantify the relationship between root parameters and soil macropore characteristics in two soil layers of Retisol from a hilly landscape in Western Lithuania, as influenced by different land use systems. The decreases in root volume and root length density were dependent on land use and soil depth. The values of root length density and root volume at $0-20 \mathrm{~cm}$ depth tended to decrease in the following order: grassland $>$ forest $>$ arable land under conventional tillage. The highest volume in the framework of macropores was recorded for medium-size pores under arable land (3.02\%), for fine pores $(2.56 \%)$ in forest soil and very fine pores in grassland soil (below $1.19 \%$ ) at the $0-10 \mathrm{~cm}$ soil depth, while at $10-20 \mathrm{~cm}$ soil depth, the coarse macropores dominated in the arable land system (below $1.41 \%)$. Root length density, root volume and the volume of very fine macropores had close relationships $(\mathrm{p}<0.01, \mathrm{r}=0.91$ and $\mathrm{r}=0.68$, respectively) under different land use at $0-20 \mathrm{~cm}$ depth. In Retisol, the roots were concentrated at $0-10 \mathrm{~cm}$ soil depth, and their volume was higher compared to the $10-20 \mathrm{~cm}$ depth. Plant roots increased the volume of very fine macropores in all land use systems, within the entire $0-20 \mathrm{~cm}$ soil depth.

Keywords: plough layer, porosity, root length, root volume, tillage, X-ray computed tomography

\section{INTRODUCTION}

Studies concerning the relationships between the macropore networks in the soil and plant roots under different land uses are of great interest, since the soil macropores affect the conductivity of water, air, and mineral solutions in the soil.
\end{abstract}

*Corresponding author e-mail: mykola.kochiieru@lammc.lt
The macropores of the soil are large soil voids. Plant roots use them as paths for growth. The wormholes, soil cracks and voids between aggregates are often associated with a high degree of variability in the transport of the gases, moisture (Helliwell et al., 2013), and dissolved substances through the soil (Hu et al., 2010, 2016, 2019).

Many studies have shown that soil porosity and soil infiltration can be induced by plant roots (Li et al., 2009, 2013; Wu et al., 2017). Van Schaik (2009) found that macropores in the soil formed by plant roots are a major factor affecting downward water movement in pastures. A recent study has revealed that the complexity of macropore networks may be linked with the age of the soil in the pedogenesis process (Musso et al., 2019).

X-ray computed tomography (CT) is one of the latest methods for studying macropores in the soil (Dal Ferro et al., 2014; Zhang et al., 2017) and preferential water flow (Gunde et al., 2010; Sammartino et al., 2012). This method is more accurate and has a higher resolution than traditional methods, such as spectral analysis, dye tracking, and the image analysis of soil thin sections. In recent times, many studies related to the parameters of the structure of macropores (which include characterizations such as macroporosity, volume, distribution of macropore size, tortuosity and surface area) have been carried out using X-ray CT for various types of soil, and various systems of land use and management (Hu et al., 2015; Katuwal et al., 2015; Kochiieru et al., 2018; Larsbo et al., 2014).

(C) 2020 Institute of Agrophysics, Polish Academy of Sciences (c) (1) $\Theta$ 
Reconstruction, which is the quantification of networks of three-dimensional macropores and the visualization of macropores are important for correlating the parameters of macropores in the soil with the physical functions of macropores and also for predicting their dynamics for various types of soil and land uses. Various types of macropores function differently due to their specific geometric shapes (Luo et al., 2008).

Soil type and land management are among of the main factors that have an influence over the parameters of macropores in the soil (Luo et al., 2010). The characteristics of soil macropores are important for a wide range of essential properties of the soil such as friability (Munkholm et al., 2012).

This study aimed to quantify the relationship between the characteristics of plant root parameters and soil macropores under different land use management: grassland, forest and arable land under conventional tillage.

\section{MATERIALS AND METHODS}

The experiment was conducted near Bijotai village $\left(55^{\circ} 31^{\prime} 12^{\prime \prime} \mathrm{N}, 22^{\circ} 36^{\prime} 55^{\prime \prime} \mathrm{E}\right)$, Šilalè district, Western Lithuania. The climate of the study site is semi-continental with an average annual temperature of $6^{\circ} \mathrm{C}$, and an average annual rainfall of $1276 \mathrm{~mm}$. The soil of the experimental site is classified as Dystric Retisol (Loamic, Bathygleyic) according to WRB (2015). Samples were taken from two soil layers (0-10 and 10-20 cm depths) of: 1) arable land managed under conventional tillage, winter wheat (Triticum aestivum $\mathrm{L}$.) was the crop grown; 2) grassland with the following prevailing grass species: cocksfoot grass (Dactylis glomerata L.), sheep fescue (Festuca ovina L.), autumn hawkbit (Leontodon autumnalis L.), common dandelion (Taraxacum officinale L.), and white clover (Trifolium repens L.) and 3) forest soil with the following prevailing tree species: Norway maple (Acer platanoides L.), European oak (Quercus robur L.), and grasses: ground elder (Aegopodium podagraria L.), wood anemones (Anemone nemorosa L.) and unspotted lungwort (Pulmonaria obscu$r a \mathrm{~L}$.). The basic soil properties are provided in Table 1.
Soil monoliths (soil cylinder $-46 \mathrm{~mm}$ in diameter and $50 \mathrm{~mm}$ in length) were sampled from each variety of land use at 3-8 and 15-20 cm depths of soil under different land uses in May 2017. The collected samples (cylinders) were secured with two plastic caps for the purposes of natural soil water content preservation and stored in a refrigerator at a constant $3-4^{\circ} \mathrm{C}$ until analysed. The analysis of the soil macropore networks was conducted at the Institute of Agrophysics, Polish Academy of Sciences, Laboratory of X-ray Computed Tomography. Each X-ray computational tomography (XRT) scan was performed as a single measurement. The scan resolution, i.e. voxel size was $0.0215 \times 0.0215 \times 0.0215 \mathrm{~mm}$. The XRT acquisition parameters were as follows: X-ray source voltage $150 \mathrm{kV}, \mathrm{X}$-ray source current $40 \mu \mathrm{A}$ and $0.2 \mathrm{~mm} \mathrm{Cu}$ filter were used to avoid any beam hardening effect. During the XRT scan, the samples were rotated $360^{\circ}$. The recorded $12002 \mathrm{D}$ radiograms were the averages of 12 2D images taken at the same angular position in order to minimize detector noise. The next step was a 3D soil sample image reconstruction based on recorded 2D radiograms. A reconstruction was conducted using software DatosX 2.0 (GE Sensing \& Inspection Technologies $\mathrm{GmbH}$ ). As a result, 16 bit grey-level 3D images were generated. An image analysis was performed using VG Studio Max 2.0 (Volume Graphics GmbH, Germany), Fiji (National Institutes of Health, USA) and software Avizo 9 (Field Electron and Ion Company, USA). The first step was the region of interest (ROI) selection and the extraction of the soil core image from the whole 3D scanned volume. Cylindrical ROI size was: $44.8 \mathrm{~mm}$ in diameter and $38.2 \mathrm{~mm}$ in height. The next step included median filtering with a kernel size of $3 p x$ to minimize the noise before thresholding the images. Thresholding was implemented using the IsoData algorithm (Ridler, Calvard, 1978) with a thorough inspection of the thresholder images. After that, the labelling of the detected pores was performed. Any group of voxels connected by at least one voxel face was treated as an individual pore. As a result of this labelling, the volumes, surface and equivalent diameters of the individual macropores were determined.

Table 1. Basic physical soil properties of the study site

\begin{tabular}{|c|c|c|c|c|c|c|}
\hline \multirow{2}{*}{ Land use method } & \multirow{2}{*}{$\begin{array}{l}\text { Depth } \\
(\mathrm{cm})\end{array}$} & \multicolumn{3}{|c|}{ Soil particle composition $(\%)$} & \multirow{2}{*}{ Texture } & \multirow{2}{*}{$\begin{array}{l}\text { Bulk density } \\
\quad\left(\mathrm{Mg} \mathrm{m}^{-3}\right)\end{array}$} \\
\hline & & $\begin{array}{c}\text { Sand } \\
>0.063 \mathrm{~mm}\end{array}$ & $\begin{array}{c}\text { Silt } \\
0.002-0.063 \mathrm{~mm}\end{array}$ & $\begin{array}{c}\text { Clay } \\
<0.002 \mathrm{~mm}\end{array}$ & & \\
\hline \multirow{2}{*}{$\begin{array}{l}\text { Arable land under } \\
\text { conventional tillage }\end{array}$} & $0-10$ & 40.4 & 38.6 & 21.0 & Loam & 1.58 \\
\hline & $10-20$ & 37.3 & 44.4 & 18.3 & Loam & 1.65 \\
\hline \multirow{2}{*}{ Grassland } & $0-10$ & 63.0 & 27.7 & 9.3 & Sandy loam & 1.37 \\
\hline & $10-20$ & 64.3 & 23.5 & 12.2 & Sandy loam & 1.55 \\
\hline \multirow{2}{*}{ Forest } & $0-10$ & 49.5 & 41.1 & 9.4 & Loam & 0.83 \\
\hline & $10-20$ & 42.4 & 43.2 & 14.4 & Loam & 1.23 \\
\hline
\end{tabular}


Monoliths of the soil $10 \times 10 \times 10 \mathrm{~cm}$ from two layers of the topsoil $(0-10$ and $10-20 \mathrm{~cm})$ were taken from each land use treatment. Samples (three replications) were taken at the flowering stage of plants (BBCH 61-65) from arable land, grassland and forest according to the Lapinskiene (1993) method. The collected samples were packed into plastic bags and stored in a freezer at $-20^{\circ} \mathrm{C}$ until they were analysed. Before analysis, the soil samples with roots were carefully washed with water using $500 \mu \mathrm{m}$ and $250 \mu \mathrm{m}$ sieves. Admixtures were removed from the washed roots. The roots were dyed with 'Neutral Red' reagent and chopped into $2 \mathrm{~cm}$ - long pieces. An analysis of the root length density, the volume of the root and also the mean root diameter was conducted using the software WinRhizo (Arsenault et al., 1995; Bouma et al., 2000).

The statistical significance of the differences between the mean values were assessed using Fisher's least significant difference (LSD) test at the probability level $\mathrm{p}<0.05$. Pearson correlation analyses of the relationship between the different parameters were also carried out.

\section{RESULTS AND DISCUSSION}

The six columns of soil from different land uses (forest, grassland and arable land) and soil depths $(3-8$ and $15-20 \mathrm{~cm})$ are presented in Figs 1 and 2 in the form of 3D visualiza- tions of macropores in the soil. According to literature, the formation of smaller macropores is influenced by freezing and thawing, or the wetting and drying processes occurring in the soil (Hellner et al., 2018; Luo et al., 2010).

Soil macropores from a depth of 3-8 $\mathrm{cm}$ are presented in Fig. 1. It may be stated that macropores are more abundant in the soil from grassland than from arable land and forest soil. At both depths (3-8 and 15-20 cm) of grassland soil, the influence of the roots of the perennial grasses on macroporosity was observed. Similar results were published by Kuka et al. (2013) (Fig. 1).

The parameters of the soil macropores differed depending on the soil depths and land use system. Figure 3 shows the volumes of various macropore sizes in the soil samples.

The characteristics of the soil macropores from different land use systems and two soil depths are presented in Table 2.

The macroporosity from the $3-8 \mathrm{~cm}$ soil depth of forest was found to be the highest $-0.039 \mathrm{~m}^{3} \mathrm{~m}^{-3}$. It was approximately three times higher compared to the $15-20 \mathrm{~cm}$ depth of the grassland soil $\left(0.015 \mathrm{~m}^{3} \mathrm{~m}^{-3}\right)$, and forest soil $\left(0.012 \mathrm{~m}^{3} \mathrm{~m}^{-3}\right)$, and about two times higher compared to the 3-8 $\mathrm{cm}$ depth of the arable land under conventional tillage $\left(0.029 \mathrm{~m}^{3} \mathrm{~m}^{-3}\right)$ and the same depth of grassland soil $\left(0.023 \mathrm{~m}^{3} \mathrm{~m}^{-3}\right)$. Luo et al. (2010) reported that one of the a

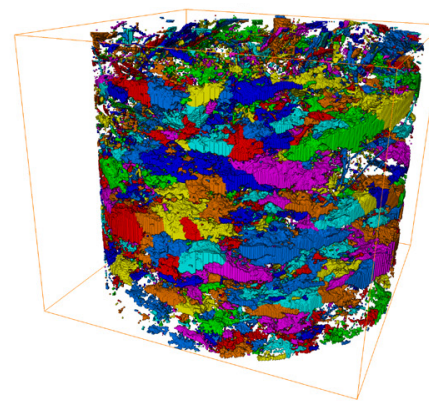

$\mathrm{b}$

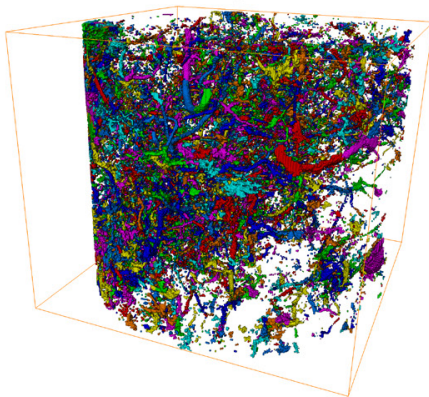

c

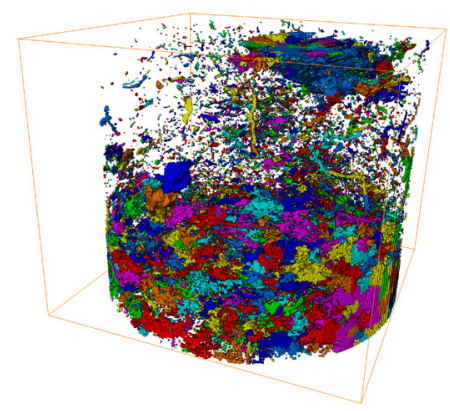

Fig. 1. Three-dimensional (3D) visualization of soil macropore networks for the soil columns in Retisol of: a - arable land under conventional tillage, $\mathrm{b}$ - grassland and $\mathrm{c}$ - forest at 3-8 $\mathrm{cm}$ depth. Different colours are used for distinguishing between individual pores detected by labelling procedure.

a

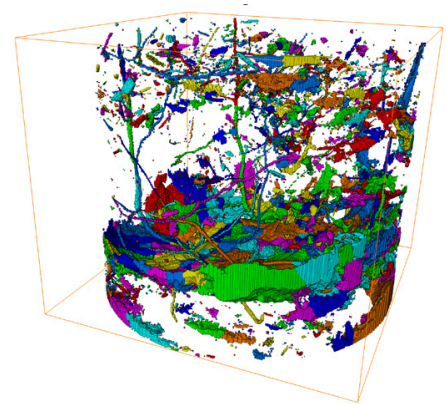

b

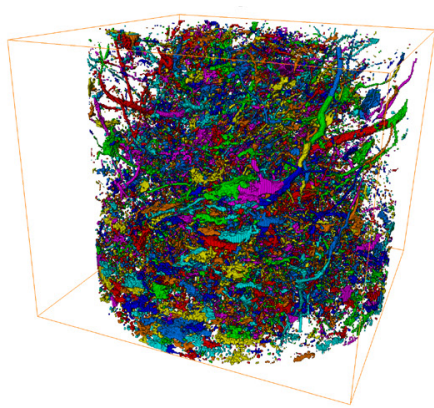

C

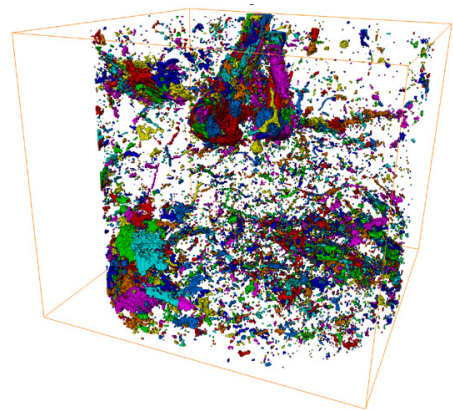

Fig. 2. Three-dimensional (3D) visualization of soil macropore networks for soil columns in Retisol of: a - arable land under conventional tillage, $\mathrm{b}$ - grassland and $\mathrm{c}-$ forest at a depth of 15-20 cm. Explanations as in Fig. 1. 


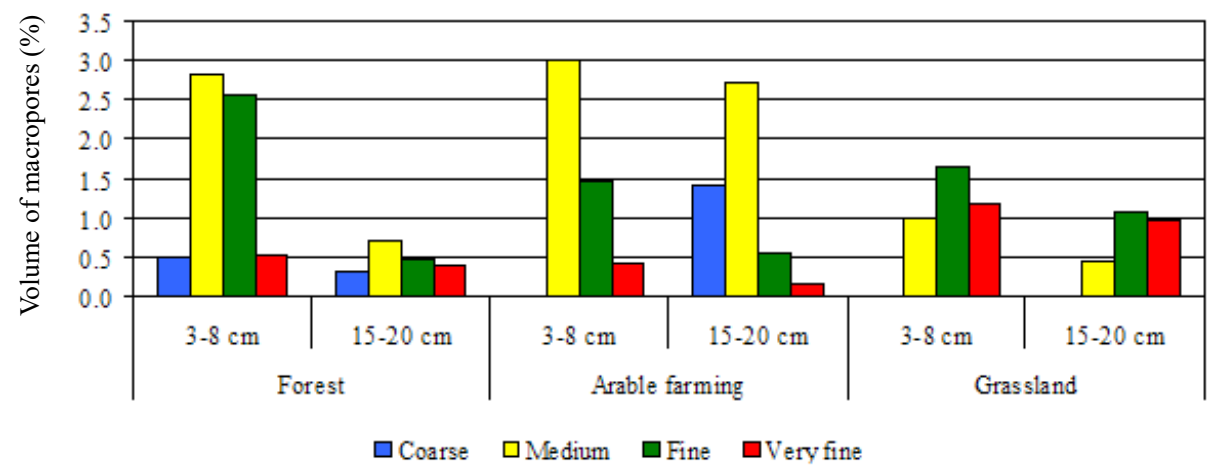

Fig. 3. Volumes of different sizes of macropores under contrasting land use methods.

Table 2. Macropore characteristics under different land uses and soil depths

\begin{tabular}{lcccc}
\hline Land use & $\begin{array}{c}\text { Depth } \\
(\mathrm{cm})\end{array}$ & $\begin{array}{c}\text { Macroporosity } \\
\left(\mathrm{m}^{3} \mathrm{~m}^{-3}\right)\end{array}$ & $\begin{array}{c}\text { Total surface area } \\
\left(\mathrm{mm}^{2}\right)\end{array}$ & $\begin{array}{c}\text { Mean pore diameter } \\
(\mathrm{mm})\end{array}$ \\
\hline $\begin{array}{l}\text { Arable land under } \\
\text { conventional tillage }\end{array}$ & $3-8$ & 0.029 & 25934.2 & 0.27 \\
& $15-20$ & 0.029 & 15111.5 & 0.33 \\
Grassland & $3-8$ & 0.023 & 32484.9 & 0.22 \\
& $15-20$ & 0.015 & 23826.3 & 0.23 \\
Forest & $3-8$ & 0.039 & 37830.5 & 0.26 \\
& $15-20$ & 0.012 & 13055.8 & 0.24 \\
\hline
\end{tabular}

main factors affecting the difference between pasture and arable land soil was the increased earthworm activity under perennial grassland. In addition, the significant development of plant roots under pastures resulted in a large number of macropores in the soil (Hu et al., 2019). Our results have revealed that in arable land under conventional tillage, the same macroporosity $\left(0.029 \mathrm{~m}^{3} \mathrm{~m}^{-3}\right)$ was observed at both (3-8 and 15-20 cm) soil depths. This may be explained by top-soil layer homogenization due to annual mouldboard ploughing.

The type of land use system and the depth of the soil influenced the total surface area and density of the macropore network. The 3-8 $\mathrm{cm}$ soil depth sample from the forest had the greatest total surface area for the entire column $\left(37830.5 \mathrm{~mm}^{2}\right)$ and macroporosity $\left(0.039 \mathrm{~m}^{3} \mathrm{~m}^{-3}\right)$, while the sample from the $15-20 \mathrm{~cm}$ soil depth had the lowest $-13055.8 \mathrm{~mm}^{2}$ total surface area and $\left(0.012 \mathrm{~m}^{3} \mathrm{~m}^{-3}\right)$ macroporosity.

The size of the macropores were classified as: coarse $>5000 \mu \mathrm{m}$, medium 2000-5000 $\mu \mathrm{m}$, fine 1000-2000 $\mu \mathrm{m}$ and very fine 75-1 $000 \mu \mathrm{m}$ according to Brewer (1964).

Table 2 shows the range of macropore size distribution in the soil for different land uses and soil depths, while Table 3 presents a matrix of the correlation between the volumes of the macroporosity of different sizes of macropores from the two depths of the soil sampled (3-8 and 15-20 cm).
The soil samples from a 3-8 $\mathrm{cm}$ depth showed significant correlations $(p<0.01)$ between the volumes of the coarse and fine sizes of macropores as well as between the volumes of the coarse and very fine sizes of macropores. A significant correlation $(p<0.01)$ was also recorded between the volumes of fine and very fine sizes of macropores in the soil samples from a depth of $15-20 \mathrm{~cm}$. All of the soil samples revealed negative relationships $(p<0.01)$ between the volumes of the pore medium and the very fine sizes of the macropores.

The soil surface area, the volume of the macropores, and macropore size were highly correlated (Table 4). These results are in line with the data published by Luo et al. (2010) and Kochiieru et al. (2018).

The root characteristics under the three land uses and two soil depths $(0-10$ and $10-20 \mathrm{~cm})$ of Retisol are presented in Table 4. The root volume for the $0-10 \mathrm{~cm}$ soil depth of the grassland was the highest value recorded at $-9.83 \mathrm{~cm}^{3}$. It was about 20 times higher compared to the $10-20 \mathrm{~cm}$ soil depth of the arable land under conventional tillage $\left(0.51 \mathrm{~cm}^{3}\right)$, and about three times higher compared to the $10-20 \mathrm{~cm}$ soil depth of the grassland $\left(2.72 \mathrm{~cm}^{3}\right)$ and forest soils $\left(3.21 \mathrm{~cm}^{3}\right)$, and about twice higher compared to the $0-10 \mathrm{~cm}$ soil depth of the arable land $\left(4.12 \mathrm{~cm}^{3}\right)$ and the same depth of forest soil $\left(6.07 \mathrm{~cm}^{3}\right)$. The decrease in root volume and the root length density depended on land use and soil depth (Ning et al., 2015). The grassland sample 
Table 3. Correlation matrix of macropores with different diameters at $3-8$ and $15-20 \mathrm{~cm}$ depths

\begin{tabular}{|c|c|c|c|c|c|c|}
\hline \multirow{2}{*}{$\begin{array}{l}\text { Depth } \\
(\mathrm{cm})\end{array}$} & \multirow{2}{*}{$\begin{array}{l}\text { Macropore } \\
\text { diameter }\end{array}$} & \multicolumn{2}{|c|}{ Range (\%) } & \multicolumn{3}{|c|}{ Correlation matrix } \\
\hline & & from & to & medium & fine & very fine \\
\hline \multirow{4}{*}{$3-8$} & Coarse & 0.00 & 0.52 & 0.42 & $0.99 * *$ & $0.99 * *$ \\
\hline & Medium & 1.02 & 3.02 & 1.00 & 0.28 & $-0.99 * *$ \\
\hline & Fine & 1.47 & 2.56 & & 1.00 & -0.25 \\
\hline & Very fine & 0.45 & 1.19 & & & 1.00 \\
\hline \multirow{4}{*}{$15-20$} & Coarse & 0.00 & 1.41 & $0.99 * *$ & $-0.56^{*}$ & $-0.56^{*}$ \\
\hline & Medium & 0.47 & 2.73 & 1.00 & -0.47 & $-0.80 * *$ \\
\hline & Fine & 0.47 & 1.09 & & 1.00 & $0.90^{* *}$ \\
\hline & Very fine & 0.17 & 0.97 & & & 1.00 \\
\hline
\end{tabular}

The least significant difference at: $* \mathrm{p}<0.05$ and $* * \mathrm{p}<0.01$.

Table 4. Effects of the land use system on plant root parameters at different soil depths

\begin{tabular}{|c|c|c|c|c|c|c|}
\hline \multirow{2}{*}{ Land use } & \multicolumn{2}{|c|}{$\begin{array}{l}\text { Mean root diameter } \\
(\mathrm{mm})\end{array}$} & \multicolumn{2}{|c|}{$\begin{array}{l}\text { Root volume } \\
\qquad\left(\mathrm{cm}^{3}\right)\end{array}$} & \multicolumn{2}{|c|}{$\begin{array}{l}\text { Root length density } \\
\qquad\left(\mathrm{km} \mathrm{m}^{-3}\right)\end{array}$} \\
\hline & $0-10 \mathrm{~cm}$ & $10-20 \mathrm{~cm}$ & $0-10 \mathrm{~cm}$ & $10-20 \mathrm{~cm}$ & $0-10 \mathrm{~cm}$ & $10-20 \mathrm{~cm}$ \\
\hline $\begin{array}{l}\text { Arable land } \\
\text { under } \\
\text { conventional } \\
\text { tillage }\end{array}$ & $0.47 \pm 0.03 \mathrm{a}$ & $0.25 \pm 0.002 \mathrm{~b}$ & $4.12 \pm 0.22 \mathrm{~b}$ & $0.51 \pm 0.04 \mathrm{~b}$ & $245.7 \pm 30.8 \mathrm{~b}$ & $106.3 \pm 10.7 \mathrm{~b}$ \\
\hline Grassland & $0.68 \pm 0.16 \mathrm{a}$ & $0.23 \pm 0.002 \mathrm{~b}$ & $9.83 \pm 2.01 \mathrm{a}$ & $2.72 \pm 0.27 \mathrm{a}$ & $1517.3 \pm 95.1 \mathrm{a}$ & $671.6 \pm 63.2 \mathrm{a}$ \\
\hline Forest & $0.48 \pm 0.07 \mathrm{a}$ & $0.72 \pm 0.130 \mathrm{a}$ & $6.07 \pm 0.45 \mathrm{ab}$ & $3.21 \pm 0.49 \mathrm{a}$ & $361.3 \pm 77.8 \mathrm{~b}$ & $84.6 \pm 16.1 \mathrm{~b}$ \\
\hline & & & Contrasts & & & \\
\hline $\begin{array}{l}\text { Forest } v s \text { arable } \\
\text { land }\end{array}$ & $0.01 \mathrm{~ns}$ & $0.47 * *$ & $1.95 \mathrm{~ns}$ & $2.70 * *$ & $115.6 \mathrm{~ns}$ & $-21.7 \mathrm{~ns}$ \\
\hline $\begin{array}{l}\text { Forest } v s \\
\text { grassland }\end{array}$ & $-0.20 \mathrm{~ns}$ & $0.49 * *$ & $-3.76 \mathrm{~ns}$ & $0.49 \mathrm{~ns}$ & $-1156.0 * *$ & $-587.0 * *$ \\
\hline $\begin{array}{l}\text { Grassland } v s \\
\text { arable land }\end{array}$ & $0.21 \mathrm{~ns}$ & $-0.02 \mathrm{~ns}$ & $5.71^{*}$ & $2.21 * *$ & $1271.6^{* *}$ & $565.3^{* *}$ \\
\hline
\end{tabular}

$\mathrm{a}-\mathrm{b}$ indexes mean different groups of means according to the Fisher's test at the significance level of $\mathrm{p}<0.05$, mean \pm standard error (SE); the least significant difference at: ${ }^{*} \mathrm{p}<0.05$ and ${ }^{*} \mathrm{p}<0.01, \mathrm{~ns}-$ not significant.

(0-10 $\mathrm{cm}$ soil depth) had the greatest root length density $\left(1517.3 \mathrm{~km} \mathrm{~m}^{-3}\right)$ and mean root diameter $(0.68 \mathrm{~mm})$, while the arable land under conventional tillage $(10-20 \mathrm{~cm}$ soil depth) had the lowest $-106.3 \mathrm{~km} \mathrm{~m}^{-3}$ root length density and mean root diameter $(0.25 \mathrm{~mm})$. The distribution of roots under the grassland is different from that in arable land (Luo et al., 2010).

The correlation matrix between the investigated root characteristics and root volume is presented in Table 5. Significant correlations between root volume and mean root diameter $(\mathrm{p}<0.01)$ and between root volume and root length density $(\mathrm{p}<0.05)$ were recorded under grassland and arable land under conventional tillage at $0-20 \mathrm{~cm}$ soil depth. No such relationships were established in forest soil at this depth. Relationships $(\mathrm{p}<0.05)$ between the mean root diameter and the root length density were observed in both the grassland and arable land use system of Retisol. A negative correlation was established in the forest soil because the samples had roots with a diameter of more than $10 \mathrm{~mm}$.

The results of correlation analyses comparing the volumes of different pores and root characteristics for different land uses and depths of Retisol are shown in Table 6.

It was revealed that the root volume was significantly $(p<0.01)$ correlated with the volume of fine and very fine macropores $(r=0.61$ and $r=0.68$, respectively). Also, the root length density had a positive correlation with the volume of very fine macropores $(r=0.91, p<0.01)$. 
Table 5. Correlation matrix among different plant root characteristics at $0-20 \mathrm{~cm}$ soil depth under different land use systems

\begin{tabular}{|c|c|c|c|c|c|}
\hline \multirow{2}{*}{ Land use } & \multirow{2}{*}{ Root characteristics } & \multicolumn{2}{|c|}{ Range } & \multicolumn{2}{|c|}{ Correlation matrix } \\
\hline & & from & to & root volume & root length density \\
\hline \multirow{3}{*}{$\begin{array}{l}\text { Arable land under } \\
\text { conventional tillage }\end{array}$} & mean root diameter $(\mathrm{mm})$ & 0.24 & 0.52 & $0.97 * *$ & 0.78 \\
\hline & root volume $\left(\mathrm{cm}^{3}\right)$ & 0.42 & 4.47 & 1.00 & $0.91 *$ \\
\hline & root length density $\left(\mathrm{km} \mathrm{m}^{-3}\right)$ & 85.90 & 307.30 & & 1.00 \\
\hline \multirow{3}{*}{ Grassland } & mean root diameter $(\mathrm{mm})$ & 0.22 & 1.01 & $0.98 * *$ & 0.81 \\
\hline & root volume $\left(\mathrm{cm}^{3}\right)$ & 2.43 & 13.74 & 1.00 & $0.89 *$ \\
\hline & root length density $\left(\mathrm{km} \mathrm{m}^{-3}\right)$ & 584.10 & 1662.00 & & 1.00 \\
\hline \multirow{3}{*}{ Forest } & mean root diameter $(\mathrm{mm})$ & 0.39 & 0.99 & -0.35 & -0.78 \\
\hline & root volume $\left(\mathrm{cm}^{3}\right)$ & 2.35 & 6.86 & 1.00 & 0.76 \\
\hline & root length density $\left(\mathrm{km} \mathrm{m}^{-3}\right)$ & 53.10 & 445.30 & & 1.00 \\
\hline
\end{tabular}

The least significant difference at: $* \mathrm{p}<0.05$ and $* * \mathrm{p}<0.01$.

Table 6. Correlation matrix among variously sized volumes of pores and root characteristics for different land uses and depths

\begin{tabular}{|c|c|c|c|c|c|c|c|c|}
\hline \multirow[b]{2}{*}{ Properties } & \multicolumn{8}{|c|}{ Correlation matrix } \\
\hline & coarse & medium & fine & very fine & $\begin{array}{l}\text { macro- } \\
\text { porosity }\end{array}$ & $\begin{array}{l}\text { mean root } \\
\text { diameter }\end{array}$ & $\begin{array}{c}\text { root } \\
\text { volume }\end{array}$ & $\begin{array}{c}\text { root } \\
\text { length } \\
\text { density }\end{array}$ \\
\hline Coarse $(\%)$ & 1.00 & & & & & & & \\
\hline Medium (\%) & $0.47 *$ & 1.00 & & & & & & \\
\hline Fine $(\%)$ & -0.30 & 0.38 & 1.00 & & & & & \\
\hline Very fine $(\%)$ & $-0.71 *$ & $-0.63 * *$ & 0.34 & 1.00 & & & & \\
\hline Macroporosity (\%) & 0.36 & $0.89 * *$ & $0.71 * *$ & -0.29 & 1.00 & & & \\
\hline $\begin{array}{l}\text { Mean root } \\
\text { diameter }(\mathrm{mm})\end{array}$ & -0.34 & -0.26 & 0.10 & 0.18 & -0.17 & 1.00 & & \\
\hline Root volume $\left(\mathrm{cm}^{3}\right)$ & $-0.56^{*}$ & -0.16 & $0.61 * *$ & $0.68 * *$ & 0.14 & $0.67 * *$ & 1.00 & \\
\hline Root length density $\left(\mathrm{km} \mathrm{m}^{-3}\right)$ & $-0.49 *$ & -0.43 & 0.35 & $0.91 * *$ & -0.10 & 0.21 & $0.75 * *$ & 1.00 \\
\hline
\end{tabular}

The least significant difference at: ${ }^{*} \mathrm{p}<0.05$ and $* * \mathrm{p}<0.01$.

A significant correlation between macroporosity and root density for enclosed shrub lands and grazed shrub lands was recorded by $\mathrm{Hu}$ et al. (2019).

\section{CONCLUSIONS}

1. In Retisol, roots were concentrated in the $0-10 \mathrm{~cm}$ soil layer in arable land under conventional tillage, grassland and forest, and their volume was higher than in the 10-20 cm soil depth.

2. Plant roots increased the volume of very fine macropores in all land use systems, within the entire $0-20 \mathrm{~cm}$ soil depth.

\section{ACKNOWLEDGEMENTS}

Soil investigation involving X-ray computed tomography was supported by the Lithuanian Academy of Sciences and the Institute of Agrophysics, Polish Academy of Sciences in Lublin.

Research findings were obtained through the long-term Research programme "Productivity and sustainability of agricultural and forest soils" implemented by Lithuanian Research Centre for Agriculture and Forestry.

Conflict of interest: The authors declare no conflict of interest. 


\section{REFERENCES}

Arsenault J.L., Poulcur S., Messier C., and Guay R., 1995. WinRHIZOTM, a root measuring system with a unique overlap correction method. HortSci., 30: 906. https://doi. org/10.21273/hortsci.30.4.906d

Bouma T.J. , Nielsen K.L., and Koutstaal B., 2000. Sample preparation and scanning protocol for computerized analysis of root length and diameter. Plant Soil, 218(2), 185-196.

Brewer R., 1964. Fabric and mineral analysis of soils. John Wiley and Sons, New York, USA.

Dal Ferro N., Sartori L., Simonetti G., Berti A., and Morari F., 2014. Soil macro- and microstructure as affected by different tillage systems and their effects on maize root growth. Soil Till. Res., 140: 55-65. https://doi.org/10.1016/j. still.2014.02.003

Gunde A.C., Bera B., and Mitra S.K., 2010. Investigation of water and $\mathrm{CO}_{2}$ (carbon dioxide) flooding using micro-CT (micro-computed tomography) images of Berea sandstone core using finite element simulations. Energy, 35: 52095216. https://doi.org/10.1016/j.energy.2010.07.045

Helliwell J.R., Sturrock C.J., Grayling K.M., Tracy S.R., Flavel R.J., Young I.M., Whalley W.R., and Mooney S.J., 2013. Applications of X-ray computed tomography for examining biophysical interactions and structural development in soil systems: a review. Eur. J. Soil Sci., 64: 279-297. https://doi.org/10.1111/ejss.12028

Hellner Q., Koestel J., Ulen B., and Larsbo M., 2018. Effects of tillage and liming on macropore networks derived from X-ray tomography images of a silty clay soil. Soil Use Manag., 34(2): 197-205. https://doi.org/10.1111/sum.12418

Hu Y.L., Zeng D.H., Liu Y.X., Zhang Y.L., Chen Z.H., and Wang Z.Q., 2010. Responses of soil chemical and biological properties to nitrogen addition in a Dahurian larch plantation in Northeast China. Plant Soil, 333, 81-92. https://doi.org/10.1007/s11104-010-0321-6

Hu X., Li Z.C., Li X.Y., and Liu Y., 2015. Influence of shrub encroachment on CT-measured soil macropore characteristics in the Inner Mongolia grassland of northern China. Soil Till. Res., 150: 1-9. https://doi.org/10.1016/j.still.2014. 12.019

Hu X., Li Z.C., Li X.Y., and Liu L., 2016. Quantification of soil macropores under alpine vegetation using computed tomography in the Qinghai Lake Watershed, NE QinghaiTibet Plateau. Geoderma, 264: 244-251. http://dx.doi. org/10.1016/j.geoderma.2015.11.001

Hu X., Li X., Wang P., Liu Y., Wu X., Li Z., Zhao Y., Cheng Y., Guo L., Lyu Y., and Liu L., 2019. Influence of exclosure on CT-measured soil macropores and root architecture in a shrub-encroached grassland in Northern China. Soil Till. Res., 187: 21-30. https://doi.org/10.1016/j.still.2018.10.020

IUSS Working Group WRB, 2015. World Reference Base for Soil Resources 2014, update 2015. International soil classification system for naming soils and creating legends for soil maps. World Soil Resources Reports No. 106. FAO, Rome. https://doi.org/10.1007/springerreference_76722
Katuwal S., Norgaard T., Moldrup P., Lamande M., Wildenschild D., and de Jonge L.W., 2015. Linking air and water transport in intact soils to macropore characteristics inferred from X-ray computed tomography. Geoderma, 237-238: 9-20.

https://doi.org/10.1016/j.geoderma.2014.08.006

Kochiieru M., Lamorski K., Feiza V., Feiziene D., and Volungevicius J., 2018. The effect of soil macroporosity, temperature and water content on $\mathrm{CO}_{2}$ efflux in the soils of different genesis and land management. ZemdirbysteAgriculture, 105(4): 291-298.

https://doi.org/10.13080/z-a.2018.105.037.

Kuka K., Illerhaus B., Fox C.A., and Joschko M., 2013. X-ray computed microtomography for the study of the soil-root relationship in grassland soils. Vadose Zone J., https://doi. org/10.2136/vzj2013.01.0014.

Lapinskienė N., 1993. Ecomorphological, quantitative and phytoestimational assessment of the underground organs of the herbal communities of the ecosystems of Lithuania: a reference to the habilitation work of the natural sciences (in Lithuanian). Vilnius, $45 \mathrm{p}$.

Larsbo M., Koestel J., and Jarvis N., 2014. Relations between macropore network characteristics and the degree of preferential solute transport. Hydrol. Earth Syst. Sci., 18: 5255-5269. https://doi.org/10.5194/hess-18-5255-2014

Li X.Y., Yang Z.P., Li Y.T., and Lin H., 2009. Connecting ecohydrology and hydropedology in desert shrubs: Stemflow as a source of preferential flow in soils. Hydrol. Earth Sci., 13: 2023-2030. https://doi.org/10.5194/hess-13-1133-2009

Li X.Y., Hu X., Zhang Z.H., Peng H.Y., Zhang S.Y., Li G.Y., Li L., and Ma Y.J., 2013. Shrub hydropedology: preferential water availability to deep soil layer. Vadose Zone J., 12(4): 1539-1663. https://doi.org/10.2136/vzj2013.01.0006

Luo L. F., Lin H.S., and Halleck P., 2008. Quantifying soil structure and preferential flow in intact soil using X-ray computed tomography. Soil Sci. Soc. America J., 72: 10581069. https://doi.org/10.2136/sssaj2007.0179

Luo L., Lin H., and Li S., 2010. Quantification of 3-D soil macropore networks in different soil types and land uses using computed tomography. J. Hydrol., 393 (1-2): 53-64. https://doi.org/10.1016/j.jhydrol.2010.03.031

Munkholm L.J., Heck R.J., and Deen B., 2012. Soil pore characteristics assessed from X-ray micro-CT derived images and correlations to soil friability. Geoderma, 181-182: 22-29. https://doi.org/10.1016/j.geoderma.2012.02.024

Musso A., Lamorski K., Slawiński C., Geitner C., Hunt A., Greinwald K., and Egli M., 2019. Evolution of soil pores and their characteristics in a siliceous and calcareous proglacial area. Catena, 182, https://doi.org/10.1016/j. catena.2019.104154

Ning S., Shi J., Zuo Q., Wang S., and Ben-Gal A., 2015. Generalization of the root length density distribution of cotton under film mulched drip irrigation. Field Crops Res., 177: 125-136. https://doi.org/10.1016/j.fcr.2015.03.012

Ridler T.W. and Calvard S., 1978. Picture thresholding using an iterative selection method. IEEE Transactions on Systems, Man, and Cybernetics, 8(8): 630-632. https://doi. org/10.1109/tsmc. 1978.4310039 
Sammartino S., Michel E., and Capowiez Y., 2012. A novel method to visualize and characterize preferential flow in undisturbed soil cores by using multi-slice helical CT. Vadose Zone J., 11: 1-13. https://doi.org/10.2136/ vzj2011.0100

Van Schaik N.L.M.B., 2009. Spatial variability of infiltration patterns related to size characteristics in a semi-arid watershed. Catena, 78: 36-47. https://doi.org/10.1016/j. catena.2009.02.017
Wu G.L., Liu Y., Yang Z., Cui Z., Deng L., Chang X.F., and Shi Z.H., 2017. Root channels to indicate the increase in soil matrix water infiltration capacity of arid reclaimed mine soils. J. Hydrol., 546: 133-139. https://doi.org/10.1016/j. jhydrol.2016.12.047

Zhang J., Xu Z., Li F., Hou R., and Ren Z., 2017. Quantification of 3D macropore networks in forest soils in Touzhai valley (Yunnan, China) using X-ray computed tomography and image analysis. J. Mountain Sci., 14(3), 474-491. https:// doi.org/10.1007/s11629-016-4150-9 